\title{
The potential use of mesenchymal stem cells in hematopoietic stem cell transplantation
}

\begin{abstract}
Eun-Jung Kim ${ }^{1,2}$, Nayoun Kim ${ }^{1,2}$ and Seok-Goo Cho ${ }^{1,2,3}$
In the last 10 years, mesenchymal stem cells (MSCs) have emerged as a therapeutic approach to regenerative medicine, cancer, autoimmune diseases, and many more due to their potential to differentiate into various tissues, to repair damaged tissues and organs, and also for their immunomodulatory properties. Findings in vitro and in vivo have demonstrated immune regulatory function of MSCs and have facilitated their application in clinical trials, such as those of autoimmune diseases and chronic inflammatory diseases. There has been an increasing interest in the role of MSCs in allogeneic hematopoietic stem cell transplantation (HSCT), including hematopoietic stem cell engraftment and the prevention and treatment of graft-versus-host disease (GVHD), and their therapeutic potential has been reported in numerous clinical trials. Although the safety of clinical application of MSCs is established, further modifications to improve their efficacy are required. In this review, we summarize advances in the potential use of MSCs in HSCT. In addition, we discuss their use in clinical trials of the treatment of GVHD following HSCT, the immunomodulatory capacity of MSCs, and their regenerative and therapeutic potential in the field of HSCT. Experimental \& Molecular Medicine (2013) 45, e2; doi:10.1038/emm.2013.2; published online 10 January 2013
\end{abstract}

Keywords: clinical trials; graft-versus-host disease; hematopoietic stem cell transplantation; mesenchymal stem cells; therapeutic use; transplantation immunology

\section{INTRODUCTION}

Hematopoietic stem cell transplantation (HSCT) has been used to treat patients with various malignant and nonmalignant diseases during the last 40 years. In 1957, Thomas et al. ${ }^{1}$ first reported the infusion of bone marrow (BM) into patients who received radiation and chemotherapy. These early experiences led to the use of allogeneic HSCT to promote recovery of hematopoietic function after myeloablative therapy. In 1968, the first successful human BM transplantion (BMT) was performed by Park et al. ${ }^{2}$ By the late 1970s, Thomas et al. ${ }^{3}$ used allogenic BM from human leukocyte antigen (HLA)-identical siblings, following total body irradiation (TBI) and administration of cyclophosphamide. In vivo transplantation of BM elements suggested that mesenchymal stem cells (MSCs) were precursors to BM connective tissue cells. In the 1990s, nonmyeloablative stem cell transplant was used for hematologic diseases and solid tumors. ${ }^{4,5}$ Kessinger et al. ${ }^{6,7}$ introduced the use of peripheral blood stem cells for allogeneic transplant.
The history of stem cells began with the discovery in the mid-1800s that some cells had the ability to generate other cells. $^{8}$ Stem cell studies were performed by Maximow and Friedenstein. ${ }^{9,10}$ Maximow discovered stem cells in the blood that could differentiate into various blood cells, and observed the relationship between hematopoiesis and the mesoderm during development. ${ }^{9}$ Friedenstein first isolated adult nonhematopoietic stem cells from the BM and demonstrated ectopic BM formation by transplanting marrow stromal cells. ${ }^{11}$ In the 1970s, Friedenstein et al. ${ }^{10}$ first isolated adherent stromal cells from whole BM in vitro culture. These adherent stromal cells were fibroblast-like, clonogenic cells with multilineage potential to differentiate into different mesenchymal tissues and hematopoietic-supporting stroma when a single colony-forming unit-fibroblast (CFU-F) was retransplanted in vivo. ${ }^{10}$ In the 1980s, Caplan and Owen further refined isolation methods and identified MSC markers. ${ }^{12,13}$ In 1998, Thomson et al. ${ }^{14}$ isolated cells from the inner cell mass of early embryos and developed the first

\footnotetext{
${ }^{1}$ Department of Laboratory of Immune Regulation, Convergent Research Consortium for Immunologic Disease (CRCID), Seoul, Korea; ${ }^{2}$ The Catholic University of Korea, College of Medicine, Seoul, Korea and ${ }^{3}$ Department of Hematology, Catholic Blood and Marrow Transplantation Center, Seoul St Mary's Hospital, The Catholic University of Korea, College of Medicine, Seoul, Korea

Correspondence: Professor S-G Cho, Department of Hematology, Catholic Blood and Marrow Transplantation Center, Seoul St Mary's Hospital, The Catholic University of Korea, College of Medicine, Seoul 137-701, Korea.

E-mail: chosg@catholic.ac.kr

Received 3 July 2012; accepted 6 October 2012
} 
human embryonic stem cell lines. ${ }^{14}$ Gearhart derived germ cells from fetal gonad tissue. ${ }^{15}$

Following the discovery of isolation and culture methods for MSCs, MSC-based therapies for stem cell research and clinical application began to be developed. MSCs have gained attention due to their potential for cell therapy and regenerative medicine. Recently, studies of the immune-suppressive capacity and regenerative potential of MSCs have generated clinical interest in the field of HSCT in terms of preventing graft rejection and controlling graft-versus-host disease (GVHD), as well as facilitating tissue engineering.

\section{DEFINITION OF MSCS}

MSCs, also known as mesenchymal stromal/stem cells, are non-hematopoietic. They were originally defined as self-renewing, multipotent progenitor cells with multilineage potential to differentiate into other types of cells of mesoderm origin, such as adipocytes, osteocytes, chondrocytes, tenocytes and skeletal myocytes, as well as cells of non-mesodermal origin, such as hepatocytes, neural cells and epithelial cells. ${ }^{16-19}$ MSCs were initially identified in the BM and are commonly isolated by gradient centrifugation to separate nucleated cells, followed by in vitro culture and serial passage. However, many publications suggested the lack of 'stemness' of MSCs. ${ }^{20}$ To improve the definition of MSCs, the Mesenchymal and Tissue Stem Cell Committee of the International Society for Cellular Therapy (ISCT) designated the name 'multipotent mesenchymal stromal cells' for the plastic-adherent cells found under standard culture conditions. ${ }^{20}$ The surface phenotype of culture-expanded MSCs, by the defined ISCT standards, is negative for surface CD14 or CD11b, CD45, CD34, CD79 or CD19, and HLA-DR. MSCs are generally, but not homogeneously, positive for a number of cell-surface markers, including CD73, CD90 and CD105. Also, MSCs must differentiate into bone, fat and cartilage by addition of exogenous growth factors, and must be plastic-adherent in vitro. ${ }^{21}$ Additionally, MSCs uniformly express CD49b,
CD49e, CD54, CD166, CD50, CD62L and CD106. MSCs lack expression of the co-stimulatory molecules CD80, CD86, CD40 and CD40L. ${ }^{22,23}$ Expression of chemokine receptors, including CCR1, CCR7, CXCR4, CXCR5 and the chemokine $\mathrm{CX}_{3} \mathrm{CL} 1$, by late-expanded MSCs is downregulated compared with that of early-passage expanded MSCs. ${ }^{24}$ The expression of surface antigens, including GD2, CD271 and frizzled-9, on MSCs has led to the isolation of MSCs using antibody-based immunomagnetic beads and/or fluorescence-activated cell sorting. ${ }^{25-28}$ The phenotypic markers of MSCs are summarized in Table 1; however, no single marker that definitively distinguishes MSCs from all other cell types has been identified.

Although MSCs can differentiate into various mature cells, their intrinsic capacity to secrete cytokines and growth factors at sites of tissue injury and inflammation contributes significantly to their therapeutic capacity. The production of these tropic mediators is defined by their in vivo location, niche and severity of injury. MSCs are reservoirs for the production of cytokines, chemokines and extracellular matrix components, which have the ability to support stem cell survival and proliferation. ${ }^{27,29,30}$ MSCs possess differentiation potential and may regenerate damaged or diseased tissues in vivo, as well as have a potential role in immunomodulation, providing a basis for a variety of clinical applications.

\section{SOURCE OF MSCS}

MSCs are most commonly isolated from $\mathrm{BM},{ }^{17}$ but stromal cells with identical properties of BM-derived MSCs have been identified in many other tissues. These cells have been obtained from adipose tissue, ${ }^{31-33}$ placenta, ${ }^{34}$ amniotic fluid, ${ }^{35-38}$ umbilical cord blood (UCB), ${ }^{39,40}$ connective tissues of skeletal muscle and dermis, ${ }^{41}$ dental tissue, ${ }^{42}$ and fetal tissues such as lung and blood. ${ }^{35}$ Mobilized peripheral blood cells have also been reported as a source of MSCs. ${ }^{43}$ Although reports of UCB as a source of MSCs were initially controversial, there is general agreement that MSCs do reside

Table 1 Characterization of MSCs

\begin{tabular}{|c|c|c|c|c|c|}
\hline \multirow[b]{2}{*}{ Source } & \multicolumn{2}{|c|}{ Phenotypic markers } & \multicolumn{3}{|c|}{ Other surface molecules used for isolation } \\
\hline & Negative & Positive & $\begin{array}{l}\text { Co-stimulatory } \\
\text { (low expression) }\end{array}$ & $\begin{array}{l}\text { Chemokines/receptors } \\
\text { (low expression) }\end{array}$ & Others \\
\hline \multicolumn{6}{|l|}{ Bone marrow } \\
\hline \multicolumn{6}{|l|}{ Adipose tissue } \\
\hline \multicolumn{6}{|l|}{ Placenta } \\
\hline Umbilical cord blood & CD45 & CD73 & CD86 & CCR7 & GD2 \\
\hline Connective tissues of skeletal muscle and dermis & CD34 & CD90 & CD40 & CXCR4 & CD271 \\
\hline Dental tissue & CD79 $\alpha$ or CD19 & CD105 & CD4OL & CXCR5 & Frizzled-9 \\
\hline Fetal tissue & HLA-DR & & & $\mathrm{CX}_{3} \mathrm{CL} 1$ & \\
\hline Peripheral blood cells & & & & & \\
\hline
\end{tabular}

$\mathrm{CCR}$, CC chemokine receptor; CD, cluster of differentiation; CXCR, CXC chemokine receptor; $C X_{3} C L, C X_{3} C$ chemokine; GD2, neural gaglioside; $\mathrm{HLA}$-DR, human leukocyte antigen-DR; MSC, mesenchymal stem cell. 
within cord blood and that the volume and storage time of the cord blood are critical for successful isolation of MSCs. ${ }^{39}$

The developmental relationship between these different MSCs has not yet been determined, and there is no consensus as to whether BM-derived MSCs are the same as those isolated from other tissues. Gene expression studies have demonstrated that MSC populations are highly heterogeneous, including those from the same tissue source. ${ }^{44}$ Thus, MSC gene expression profiles, including expression levels of MSC markers and some of their functional properties, differ according to the tissue source. ${ }^{45}$ With regard to their ability to renew and differentiate, all cells derived from the majority of tissues behave in a similar manner. Additionally, the major functional properties, such as regulation of immunological tolerance, wound healing, inflammation and fibrosis, are common to all MSCs. ${ }^{46}$ The heterogeneity of the MSC population suggests that different tissue sources may generate MSCs particularly suited to specific clinical applications.

\section{IMMUNOMODULATORY PROPERTIES OF MSCS}

MSCs not only provide stromal support for hematopoietic stem cells in the BM but also have potent immunosuppressive and anti-inflammatory effects. MSCs suppress T-cell proliferation induced by alloantigens or mitogens via increasing the number of regulatory $\mathrm{T}$ cells. ${ }^{47,48}$ The interactions between T cells and MSCs have significant clinical implications in HSCT. MSCs have been shown to lessen complications of GVHD after HSCT $^{49}$ and immune-mediated disease. ${ }^{50-52}$ In addition, MSCs inhibit function of B cells, ${ }^{53}$ natural killer cells ${ }^{54}$ and dendritic cells. ${ }^{55}$ The main immunosuppressive function of MSCs is to induce soluble factors, including transforming growth factor- $\beta,{ }^{56}$ hepatocyte growth factor ${ }^{57}$ nitric oxide, ${ }^{58}$ HLA-G ${ }^{59}$ and indoleamine 2,3-dioxygenase ${ }^{60}$ (Table 2); however, these cells can also exert immunosuppressive effects by direct cell-to-cell interaction. ${ }^{61}$ The immunosuppressive capacity of MSCs is enhanced under inflammatory conditions in the presence of the proinflammatory cytokines interferon (IFN) $-\gamma$, tumor necrosis factor- $\alpha$ and interleukin (IL)-6. MSCs constitutively produce large amounts of IL-6 and

Table 2 Immunomodulatory molecules produced by MSCs

\begin{tabular}{|c|c|}
\hline Molecule & Function \\
\hline Transforming growth factor- $\beta$ & Suppress T-lymphocyte proliferation \\
\hline Hepatocyte growth factor & Suppress T-lymphocyte proliferation \\
\hline Nitric oxide & $\begin{array}{l}\text { Suppress T-cell function and } \\
\text { responsiveness }\end{array}$ \\
\hline Human leukocyte antigen-G & Suppress naive T-cell proliferation \\
\hline $\begin{array}{l}\text { Indoleamine 2,3-dioxygen- } \\
\text { ase (IDO) }\end{array}$ & $\begin{array}{l}\text { IDO-mediated T-cell inhibition by convert- } \\
\text { ing tryptophan tokynurenin, a T-cell-inhibi- } \\
\text { tory effector pathway in APCs }\end{array}$ \\
\hline $\begin{array}{l}\text { Chemokines: CCL-2, ICAM-1, } \\
\text { CXCL-10, CCL-8 }\end{array}$ & Drive T-cell migration toward MSCs \\
\hline
\end{tabular}

APC, antigen-presenting cell; $\mathrm{CCL}, \mathrm{CC}$ chemokine; $\mathrm{CXCL}, \mathrm{CXC}$ chemokine; ICAM-1, intercellular adhesion molecule 1; MSC, mesenchymal stem cell.
IL-8, and the chemokine CCL-2. When MSCs were treated with IFN- $\gamma$, there was secretion of ICAM-1, CXCL-10 and CCL-8, whereas IL-8 production was decreased. ${ }^{62}$ This phenomenon suggests that MSCs target neutrophils and monocytes under non-inflammatory conditions, but attract monocytes, dendritic cells, T cells and natural killer cells under inflammatory conditions. ${ }^{62} \mathrm{~A}$ number of studies reported transforming growth factor- $\beta$ as a key mediator of immunomodulation by MSCs. There is some evidence that the transforming growth factor- $\beta$-transduced MSCs used in our study showed enhanced immunomodulatory effects on T-cell-mediated immunity. ${ }^{56}$ Under immunologically quiescent conditions, MSCs promote T-cell survival and can induce the activation and proliferation of $\mathrm{CD} 4+\mathrm{T}$ cells. ${ }^{63,64}$ The dual immunomodulatory properties of MSCs suggest that environmental factors may have a crucial role in induction of MSC-mediated immunomodulation.

Recent studies reported that MSCs must be 'licensed' to exert their immunomodulatory effects. Marigo and Dazzi ${ }^{65}$ showed that MSCs are not constitutively inhibitory, but require a licensing step to produce acute inflammatory helper T-lymphocyte (Th1)-type cytokines. If MSCs are transplanted during acute inflammation, the microenvironment containing polarized M1 macrophages 'licenses' MSCs to inhibit effector T, B, natural killer and dendritic cells. In contrast, if MSCs are licensed after the polarization of M2 macophages by Th2-type cytokines during chronic inflammation, the microenvironment provides alternative licensing and recruits MSCs to the fibrosis process. ${ }^{65}$ In conclusion, MSC therapy in an inflammatory microenvironment that is licensing-dependent. Under conditions of mild or chronic inflammation, the lack of licensing fails to provide therapeutic effects, leading to weakened MSC immunosuppressive activity.

\section{THERAPEUTIC POTENTIAL OF MSCS FOR TREATMENT OF ACUTE AND CHRONIC GVHD}

GVHD is a severe inflammatory condition, which results from immune-mediated attack of recipient tissue by donor $\mathrm{T}$ cells contained in the allogeneic graft. The immunomodulatory properties of MSCs have led to clinical trials of MSC-based therapy to prevent acute GVHD ( $a \mathrm{GVHD})$ and chronic GVHD (cGVHD), major complications that occur after allogeneic HSCT. ${ }^{66}$ For a more detailed review of GVHD, see Schroeder and DiPersio. ${ }^{67}$ Without intervention before HSCT, almost all allotransplant recipients develop significant GVHD. These data suggest that enhancing the immunomodulatory capacity of MSCs has potential for treatment of GVHD following HSCT. ${ }^{68}$ Multiple drugs and strategies are used to deplete $\mathrm{T}$ cells to prevent donor anti-host immunological complications of allotransplantation. Recently, the immunomodulatory and tissue-repair properties of MSCs have led to many studies and clinical trials of their use as a treatment for GVHD. The rationale for studies of MSCs was based on their immunomodulatory properties identified by numerous in vitro assays and in vivo models, as explained above. 
aGVHD involves direct cytotoxic effects of donor T cells on recipient tissues, activation of antigen-presenting cells and an inflammatory cascade that produces cytokines, including IL-1, IL-6, IL-12, IFN- $\gamma$ and tumor necrosis factor- $\alpha .{ }^{69}$ At first, there was a scarcity of preclinical models demonstrating the efficacy of MSCs in ameliorating $a \mathrm{GVHD}$ before clinical studies started. In fact, most preclinical models were developed after the demonstration of clinical efficacy. The clinical efficacy of MSCs in $a \mathrm{GVHD}$ was initially observed in a 9-year-old boy suffering from steroid-resistant grade IV $a \mathrm{GVHD}$ who received haploidentical third-party MSCs. ${ }^{70}$ In the next phase II clinical trial, which involved 55 patients with the same condition, the administration of MSCs significantly improved the overall survival rate. ${ }^{71}$ However, in another phase I/II clinical trial, a single infusion of MSCs given at the time of the transplant did not prevent the development of $a$ GVHD. ${ }^{72}$ This discrepency was also seen in animal models and was later explained by the findings of preclinical studies. Initial studies of MSCs in a murine $a \mathrm{GVHD}$ model demonstrated that a single infusion of MSCs at the time of HSCT did not prevent $a \mathrm{GVHD},{ }^{73}$ but this could be mitigated by multiple doses given at weekly intervals subsequent to HSCT. ${ }^{74}$ Polchert et al. ${ }^{75}$ reported that MSCs can be used to treat $a \mathrm{GVHD}$ when administered at an appropriate time in the presence of IFN- $\gamma$. That study showed that the survival rate of mice increased when MSCs were administered at day +2 or +20 of HSCT, when IFN- $\gamma$ levels were at their peak. This study demonstrated that timing was critical because an appropriate inflammatory environment was needed to 'license' the MSCs. The role of IFN- $\gamma$ and of the inflammatory environment in activation of MSCs to exhibit inhibitory activty has been described in vitro. ${ }^{76}$

It has been suggested that inflammatory cytokines, including IFN- $\gamma$, can recruit MSCs to the site of inflammation and tissue injury. ${ }^{77}$ In addition to their immunomodulatory effects, MSCs might enhance the healing of wounded tissue by providing soluble factors, transdifferentiation and cell fusion. In a previous clinical trial, patients were treated with MSCs to ameliorate tissue toxicty following $\mathrm{HSCT}^{78}$ Tissue injuries, such as hemorrhagic cystisis and pneumomediastium, were cleared in several patients after treatment with MSCs. In one patient with aGVHD, symptoms of perforated diverticulitis and peritonitis were reversed by MSC therapy ${ }^{78}$ Furthermore, a series of experiment used bioimaging to track the biodistribution of MSCs in a murine model of $a \mathrm{GVHD} .{ }^{79} \mathrm{In}$ these experiments, donor C57BL/6 splenocytes, which expressed enhanced green fluorescent protein, were used to induce $a \mathrm{GVHD}$. Then, MSCs were generated from C57BL/6 donor mice expressing red fluorescent protein (RFP). RFPMSC were injected, and both fluorescent signals were detected consistently. Enhanced green fluorescent protein was first detected in the lungs, but spread to the gastrointestinal (GI) tract, liver, skin, and lymph nodes, all of which are known clinical targets of $a \mathrm{GVHD}$. After injection, RFP signals colocalized with EGFP signals at the $a \mathrm{GVHD}$ target sites, proving that MSCs can home to sites of $a \mathrm{GVHD}$ and potentially exert direct cell-cell contact-mediated effects as well as paracrine effects for tissue repair. Murine MSCs that were engineered to express the anti-inflammatory cytokine IL-10 significantly reduced the severity of $a \mathrm{GVHD}$ compared to unmodified MSCs. ${ }^{80}$ It is likely that safely engineered MSCs may provide more targeted and effective cell therapy for $a \mathrm{GVHD}$.

cGVHD occurs after the first 100 days of HSCT and is characterized by autoimmune-like dysregulation. While $a \mathrm{GVHD}$ involves mainly the skin, liver, and GI tract, $c \mathrm{GVHD}$ affects almost any organ and reduces the quality of life, organ function, and overall survival. ${ }^{81}$ In contrast to $a \mathrm{GVHD}$, the pathophysiology of $c \mathrm{GVHD}$ is poorly understood. A clinical trial of the use of MSCs to treat $c$ GVHD has been reported recently. ${ }^{72}$ The first report involved co-transplantation of HLA-identical sibling culture-expanded MSCs with HLAidentical sibling HSCT in patients with hematologic malignancies. Clinical improvement was identified in 22 of $36(61 \%)$ patients who survived at least 90 days. ${ }^{72}$ Another report suggested that BM-derived MSCs may be used successfully to treat adult patients with sclerodermatous $c$ GVHD, ${ }^{82}$ because IFN- $\gamma$, IL-2, IL-10, and IL-4 producing cells were detected both before and after MSC infusion. Before MSC infusion, Th2-type cells were markedly increased compared to Th1 type cells, whereas after MSC infusion, the proportion of Th1 type cells increased. ${ }^{82}$ In another study, infusion of culture-expanded MSCs was investigated as a therapeutic approach for patients with steroid-resistant cGVHD. ${ }^{68}$ Although 14 of 19 patients (73.7\%) responded to MSC administration, only four patients showed complete remission. ${ }^{68}$ The majority of patients showed only partial or mixed responses, suggesting that MSC may not be a potent immunomodulator in a $c$ GVHD environment. The number of studies of use of MSCs in $c \mathrm{GVHD}$ is insufficient; it is apparent that unlike $a \mathrm{GVHD}$, the therapeutic effect of MSCs on $c \mathrm{GVHD}$ is limited.

Despite in vitro and in vivo evidence that MSCs can ameliorate GVHD, clinical trials of the treatment of GVHD remain incomplete. Our recent data showed that transforming growth factor- $\beta$-transduced MSCs were able to successfully treat autoimmune arthritis by inducing Foxp3 levels and inhibiting IL-17 production; however, MSCs themselves did not suppress IL-17 production. ${ }^{56}$ These findings suggest that while MSCs exert immunomodulatory properties via an IFN- $\gamma$ (thast is, Th1)-dominant response, MSCs may not effectively inhibit Th17 responses. While the role of Th17 in aGVHD pathogenesis is still not clearly defined, recent studies have revealed that GVHD involves a combination of both Th1 and Th17 responses; ${ }^{83}$ thus, the monitoring of both Th1 and Th17 responses, rather than Th1 or Th17 responses alone, could be an accurate indicator of GVHD severity after HSCT $^{84}$ Furthermore, Yi et al. ${ }^{85}$ suggested that blocking Th1 or Th17 cells alone was ineffective for treatment of GVHD. Blocking Th1 cells led to the exacerbation of Th17 responses, and vice versa. Thus, new studies are proposing that simultaneous inhibition of Th1 and Th17 differentiation could be a new strategy to treat GVHD following HSCT. ${ }^{86}$ Finally, a more standardized study design is needed for clinical trials, in order 
Table 3 In vivo immunosuppressive effects of MSCs

\begin{tabular}{|c|c|c|c|}
\hline Animal, model & MSCS & Outcome & Reference \\
\hline Mouse, aGVHD & Single infusion of MSCs & No effect on prevention of GVHD & Sudres et al. ${ }^{73}$ \\
\hline Mouse, aGVHD & $\begin{array}{l}\text { Multiple infusions of MSCs after HSCT, } \\
\text { once GVHD has been fully established }\end{array}$ & $\begin{array}{l}\text { Increased survival rate and } \\
\text { amelioration of disease }\end{array}$ & $\begin{array}{l}\text { Tisato et al.; }{ }^{74} \\
\text { Polchert et al..;5 } \\
\text { Joo et al. } .^{79}\end{array}$ \\
\hline Mouse, aGVHD & IL-10-transduced MSCs & Reduced severity of aGVHD & Min et al. 80 \\
\hline Mouse, graft rejection & Co-transplantation of fetal and adult human MSCs & Long-term engraftment & Almeida-Porada et al.87 \\
\hline Sheep, graft rejection & Co-transplantation of fetal and adult human MSCs & Long-term engraftment & Noort et al. 88 \\
\hline Primate, graft rejection & Autologous intra-BM transplantation of MSC & Improved engraftment & Masuda et al. ${ }^{90}$ \\
\hline Mouse, graft rejection & Allogeneic MSCs & Increased rejection & Nauta et al. ${ }^{91}$ \\
\hline Mouse, non-obese diabetic & Allogeneic MSCs & $\begin{array}{l}\text { Induction of mixed chimerism } \\
\text { and prevention of insulitis }\end{array}$ & $\begin{array}{l}\text { Asari et al. }{ }^{98} \\
\text { Itakura et al. }{ }^{99}\end{array}$ \\
\hline Mouse, chimerism & $\begin{array}{l}\text { Intra-bone marrow-bone marrow transplantation } \\
\text { with allogeneic MSCs }\end{array}$ & Induction of mixed chimerism & Wang et al. ${ }^{101}$ \\
\hline
\end{tabular}

aGVHD, acute graft-versus-host diasease; BM, bone marrow; CIA, collagen-induced arthritis; GVHD, graft-versus-host diasease; HSCT, hematopoietic stem cell transplantation; IL-10, interleukin 10; MSC, mesenchymal stem cell; TGF- $\beta$, transforming growth factor- $\beta$.

Table 4 Clinical trials of MSC therapy for hematopoietic stem cell transplantation

\begin{tabular}{|c|c|c|c|c|}
\hline Treatment of aGVHD & BM & I & CR (100\%) & Le Blanc et al. ${ }^{70}$ \\
\hline Treatment of aGVHD & BM & II & $\begin{array}{l}30 \text { CR }(54 \%) \\
9 \text { PR }(16 \%)\end{array}$ & Le Blanc et al. ${ }^{71}$ \\
\hline Prevention of aGVHD, cGVHD & $\mathrm{BM}, \mathrm{PBSC}$ & I & $\begin{array}{l}22 / 46(50 \%) \text { still developed aGVHD } \\
22 / 36(61 \%) \text { still developed cGVHD }\end{array}$ & Lazarus et al..$^{72}$ \\
\hline Treatment of cGVHD & BM & I & Decreased signs and symptoms in all patients & Zhou et al. ${ }^{82}$ \\
\hline Treatment of $c G V H D$ & BM & I & $\begin{array}{l}4 \text { CR }(21 \%) \\
10 \operatorname{PR}(52 \%)\end{array}$ & Weng et al. ${ }^{68}$ \\
\hline
\end{tabular}

aGVHD, acute GVHD; BM, bone marrow; cGVHD, chronic GVHD; CR, complete response; MSC, mesenchymal stem cell; PBSC, peripheral blood stem cell; PR, partial response.

to accurately evaluate the effects of MSCs on GVHD. Data from preclinical murine GVHD models suggest that the timing of MSC administration is critical to its effectiveness, but the optimal treatment schedule has not yet been defined. To-date a variety of dosing schedules has been used; however, the optimal treatment method should be determined. Furthermore, as mentioned above, a consensus must be formed regarding the optimal culture and manufacturing conditions to generate uniform MSCs. Therefore, more definitive studies and longer follow-ups during clinical trials are necessary to assess the long-term efficacy and toxicity associated with MSC use. In future studies, the use of genetically modified MSCs holds considerable promise. In conclusion, both preclinical (Table 3) and clinical (Table 4) trials using MSCs as a potential therapeutic agent for the treatment of GVHD are encouraging, yet the data remain incomplete.

\section{FACILITATING ENGRAFTMENT BY MSCS}

MSCs have been suggested to be the progenitor cells that modulate alloreactivity and promote hematopoietic reconstitution. Therefore, MSCs have been suggested to enhance 
engraftment and to prevent rejection after HSCT. Co-transplantation of fetal and adult human MSCs promoted longterm engraftment in immunodeficient (non-obese diabetic/ SCID) mice and fetal sheep. ${ }^{87,88}$ Infusion of allogeneic BMderived MSCs inhibited lymphocyte proliferation and prolonged skin allograft survival. ${ }^{89}$ Co-transplantation with MSCs improved HSC engraftment after autologous intra-BM (IBM) transplantation in non-human primates. ${ }^{90}$ In murine models, the infusion of host MSCs enhanced engraftment of allogeneic hematopoietic cells; however, donor MSCs increased rejection of an allogeneic stem cell graft. ${ }^{91}$ During the first clinical trial, rapid hematopoietic recovery was accelerated by the use of culture-expanded marrow MSCs and autologous blood transplantation. ${ }^{92}$ In a phase I/II clinical trial, cotransplantation of donor MSCs in 14 children given T-celldepleted HLA-disparate CD34 + cells accelerated leukocyte recovery and prevented graft rejection..$^{93}$ In a pediatric phase I/II trial, infusion of ex vivo culture-expanded thirdparty haploidentical MSCs into unrelated pediatric UCB transplantation prompted hematopoietic recovery. ${ }^{94}$ Co-infusion of parental MSCs in pediatric patients given allogeneic UCB graft prevented $a \mathrm{GVHD}$, but did not affect engraftment or hematopoietic recovery. ${ }^{94,95}$ In an adult phase I/II clinical trial, patients receiving UCB transplantation with co-infusion of third-party donor, mobilized hematopoietic stem cells did not affect the kinetics of engraftment or $a \mathrm{GVHD} .{ }^{96}$ These findings indicate that co-infusion of hematopoietic cells and MSCs is safe in vivo and clinically, while the engraftment capacity of MSCs in terms of efficacy remains uncertain.

\section{INDUCTION OF MIXED CHIMERISM USING MSCS}

Induction of mixed chimerism and achieving immunological tolerance is an important goal in the efforts to reduce the morbidity, mortality and shortage of organ transplants as well as to combat hematological malignancies. Mixed chimerism entails coexistence of recipient and donor hematopoietic cells following transplantation of donor $\mathrm{BM}$ into conditioned recipients. These protocols involve T-cell depletion, co-stimulation blockade and therapeutic use of regulatory $\mathrm{T}$ cells. ${ }^{97}$ Recent studies of MSC-mediated anti-GVHD effects, their supportive role in hematopoietic engraftment and their immunomodulatory properties have led to increasing use of MSCs in mixed chimerism protocols.

Most mixed chimerism protocols utilizing MSCs use recipient conditioning regimens to enhance the engraftment of donor BM followed by the co-administration of BM cells and MSCs. In non-obese diabetic mouse models, known to be highly resistant to chimerism induction, recipient mice were treated with a preconditioning regimen consisting of $3 \mathrm{~Gy} \mathrm{TBI}$ and anti-CD3 monoclonal antibody injection. ${ }^{98}$ The coinjection of allogeneic BM cells and MSCs facilitated engraftment, induced mixed chimerism with a success rate greater than $78 \%$, and prevented insulitis and the onset of diabetes. Furthermore, no GVHD developed with this treatment regimen. Similar results were demonstrated in streptozotocin-diabetic rats. ${ }^{99}$ The recipient rats received a conditioning regimen consisting of anti-lymphocyte serum and 5 Gy TBI, followed by co-infusion of allogeneic MSCs, BM cells and islets. Although all recipients rejected the islets initially, half developed stable mixed chimerism and donorspecific immune tolerance, shown by donor skin engraftment and a second round of islet transplants. In another experiment, recipient Lewis rats received a similar conditioning regimen consisting of anti-lymphocyte serum, rapamycin immunosuppressive therapy (from days 0 to 130) and $3 \mathrm{~Gy}$ TBI, followed by co-infusion of allogeneic MSCs and BM cells. ${ }^{100}$ Additionally, a hindlimb allotransplant was performed 30 days after the BMT. The immunosuppressive therapy was stopped 100 days after hindlimb transplantations. Fourteen of fifteen recipients developed stable and high-level chimerism, and the survival time of hindlimb allografts was prolonged even after the withdrawal of rapamycin in the group with coadministration of MSCs. In contrast, a protocol that induced mixed chimerism with no cytotoxic conditioning was evaluated. ${ }^{101}$ Wang et al. ${ }^{101}$ established mixed chimerism by IBM-BMT combined with BM-derived allogeneic MSC treatment in mice. IBM-BMT is a method that administers donor BM directly into the recipient BM. Because of the low morbidity of GVHD and rapid recovery of hematopoietic function, IBM-BMT is considered one of the best strategies, and intraosseous infusion is an established method for patients receiving critical care in the clinical setting. The donor-derived MSCs were transplanted intravenously daily for 4 days before the actual transplantation, and IBM-BMT was performed immediately after the fourth injection. The majority of the mice developed 20-25\% chimerism levels among myeloid lineage cells, whereas no chimerism was detected in either control group (IBM-BMT or BM-MSC treatment alone).

\section{MSC IMMUNOGENICITY}

MSCs are considered to be immunoprivileged because of their absent or low expression of major histocompatibility complex class II and other co-stimulatory molecules. MSCs have also been found to have an immunosuppressive role. Thus, MSCs have been assumed to be a powerful therapeutic tool that could be used regardless of the major histocompatibility complex identity between donor and recipient. However, recent research has revealed that MSCs can stimulate immune responses under certain conditions. Depending on the IFN- $\gamma$ level, MSCs can exhibit antigen-presenting properties. ${ }^{102}$ At low IFN- $\gamma$ levels, MSCs can upregulate the expression of major histocompatibility complex II and gain the ability to act as an antigen-presenting cell. ${ }^{102}$ IFN- $\gamma$-treated MSCs have also been demonstrated to induce ovalbumin-specific immune responses. ${ }^{103}$ The IFN- $\gamma$-treated syngeneic MSCs could process the ovalbumin antigen peptide, present it on major histocompatibility complex II molecules, and activate ovalbumin-specific T cells. ${ }^{103}$ MSC immunogenicity has also been demonstrated in vivo models. The presence of allogeneic MSCs in a non-myeloablative transplantation setting resulted in a significantly increased graft rejection. ${ }^{91,104,105}$ 


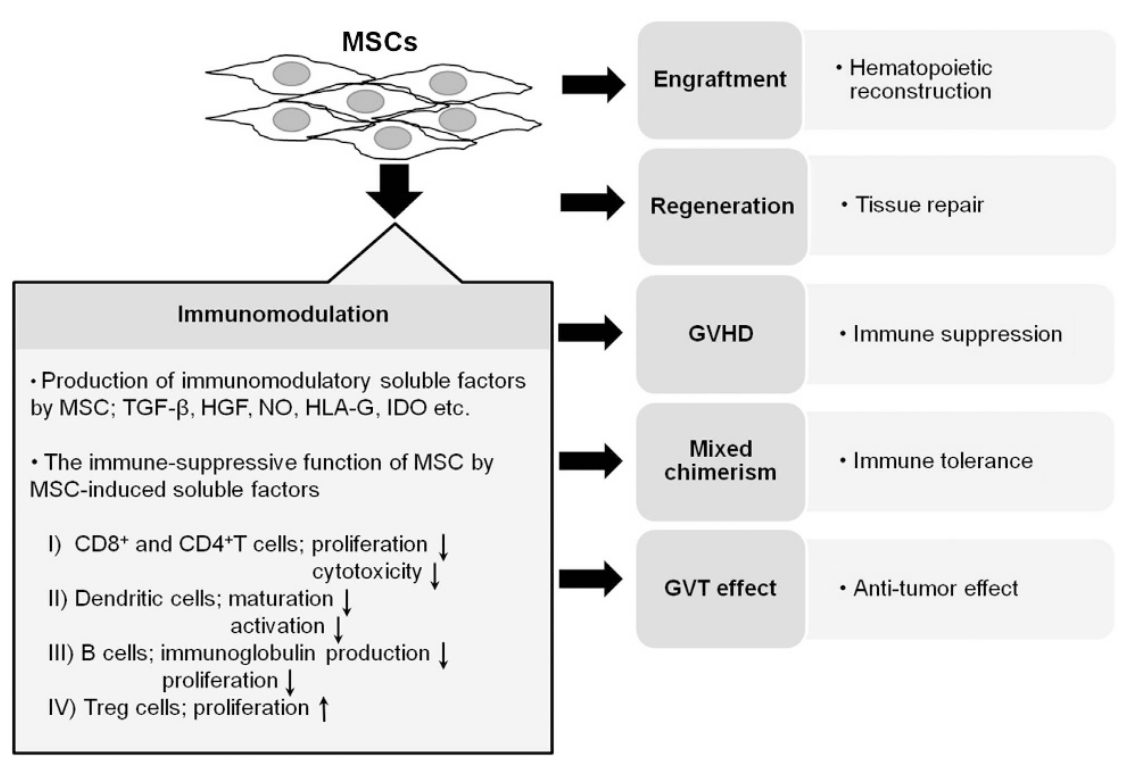

Figure 1 MSC-mediated therapies targeting for hematopoietic stem cell transplantation. The potential uses of MSCs include treatment of GVHD, facilitation of hematopcietic engraftment, induction of mixed chimerism and induction of the GVT effect. MSCs possess unique properties of immune modulation and tissue regeneration. $\downarrow$ : suppression; $\uparrow$ : promotion. GVHD, graft-versus-host disease; GVT, graftversus-tumor; HLA, human leukocyte antigen; IDO, indoleamine 2,3-dioxygenase; MSCs, mesenchymal stem cells; TGF- $\beta$, transforming growth factor- $\beta$.

Furthermore, the administration of allogeneic MSCs induced T-cell responses in naive immunocompetent host mice. It appears that MSCs can engraft immunocompromised hosts, but have limited capacity to elicit an immune response in an immunocompetent host. Many aspects of the immunogenic properties of MSCs remain to be elucidated; therefore, further studies should validate the efficacy and clinical consequences of the use of MSCs.

\section{GRAFT-VERSUS-TUMOR EFFECT FOLLOWING MSC THERAPY}

Allogeneic donor lymphocytes produce a strong graft-versustumor (GVT) effect. However, its clinical efficacy is limited by conditioning-related toxicity, GVHD, and engraftment failure. Barnes and Loutit ${ }^{106}$ first reported GVT alloreactivity of allogeneic HSCT in a murine model. The GVT response is mediated largely by minor histocompatibility antigens, ${ }^{107-109}$ natural killer cells ${ }^{110-113}$ and donor lymphocyte infusion. ${ }^{114-116}$ A major focus of allogeneic HSCT is augmentation of GVT effects without GVHD. Recent investigations have focused on infusion of cells, novel pharmacologic agents and biological agents that may specifically prevent GVHD without affecting GVT reactions. More specifically relevant to GVT effects, 20 patients with hematologic malignancies received MSCs from HLA-mismatched donors after conditioning with TBI and fludarabine. ${ }^{117}$ HLA-mismatched non-myeloablative HSCT with MSC co-infusion exhibited a therapeutic effect on the hematologic malignancies. Furthermore, the results suggested that MSC co-infusion prevented GVHD while preserving GVT effects. ${ }^{117}$ Although the induction of tumor inhibition and enhancement are polar opposites, MSCs have numerous beneficial properties in terms of promoting GVT effects due to both their immunomodulatory properties after HSCT that may suppress tumors, as well as their tropism toward the tumor microenvironment.

\section{CONCLUSION}

HSCT was initiated in 1957 by Thomas et al..$^{1}$ by the infusion of human BM into leukemia patients. Currently, a variety of stem cell sources other than the BM, such as peripheral blood, amniotic fluid and UCB, are being used in transplantation settings, and new treatment methods are continually being discovered. However, the limitations of HSCT, including infection, relapse of disease, engraftment and complications of GVHD, have not been resolved. At present, MSCs are an excellent candidate with clinical therapeutic potential for HSCT. Preclinical and clinical studies of MSC therapy are revealing new methods of overcoming these limitations. The potential uses of MSCs include treatment of GVHD, facilitation of hematopoietic engraftment, induction of mixed chimerism and induction of the GVT effect. In addition, MSCs possess unique properties of immune modulation and tissue regeneration that highlight their potential as a potent therapeutic tool (Figure 1). Based on the results of clinical studies, to improve the safety and efficiency of MSC therapy, studies of specific markers that identify MSCs, cell dose and the timing and route of administration are crucial and must continue. Furthermore, enhancement of the therapeutic activity of MSC transplants is required to increase our knowledge of how MSCs regulate the host immune response, and therefore, further studies may be needed to identify the immunoregulatory mechanisms and in vivo biological activities of MSCs after administration. 


\section{ACKNOWLEDGEMENTS}

This study was supported by a grant of the Korean Health Technology R\&D Project, Ministry for Health \& Welfare, Republic of Korea (A092258).

1 Thomas ED, Lochte HL Jr, Lu WC, Ferrebee JW. Intravenous infusion of bone marrow in patients receiving radiation and chemotherapy. $N$ Eng/ J Med 1957; 257: 491-496.

2 Park BH, Biggar WD, Good RA. Minnesota experience in bone-marrow transplantation in man, 1968 to June 1973. Transplant Proc 1974; 6: 379-383.

3 Thomas E, Storb R, Clift RA, Fefer A, Johnson FL, Neiman PE et al. Bonemarrow transplantation (first of two parts). N Engl J Med 1975; 292: 832-843.

4 Slavin S, Nagler A, Naparstek E, Kapelushnik Y, Aker M, Cividalli G et al. Nonmyeloablative stem cell transplantation and cell therapy as an alternative to conventional bone marrow transplantation with lethal cytoreduction for the treatment of malignant and nonmalignant hematologic diseases. Blood 1998; 91: 756-763.

5 Srinivasan R, Barrett J, Childs R. Allogeneic stem cell transplantation as immunotherapy for nonhematological cancers. Semin Oncol 2004; 31: 47-55.

6 Kessinger A, Smith DM, Strandjord SE, Landmark JD, Dooley DC, Law P et al. Allogeneic transplantation of blood-derived, T cell-depleted hemopoietic stem cells after myeloablative treatment in a patient with acute lymphoblastic leukemia. Bone Marrow Transplant 1989; 4: 643-646.

7 To LB, Roberts MM, Haylock DN, Dyson PG, Branford AL, Thorp D et al. Comparison of haematological recovery times and supportive care requirements of autologous recovery phase peripheral blood stem cell transplants, autologous bone marrow transplants and allogeneic bone marrow transplants. Bone Marrow Transplant 1992; 9: 277-284.

8 Cohnheim J. Über Entzündung and Eiterung. J Arch Path Anat Physiol Klin Med 1924; 40: 1-79.

9 Maximow A. Relation of blood cells to connective tissues and endothelium. Physiol Rev 1924; 4: 533-563.

10 Friedenstein AJ, Chailakhjan RK, Lalykina KS. The development of fibroblast colonies in monolayer cultures of guinea-pig bone marrow and spleen cells. Cell Tissue Kinet 1970; 3: 393-403.

11 Afanasyev BV, Elstner E, Zander AR. A.J. Friedenstin, founder of the mesenchymal stem cell concept. Cell Ther Transplant 2009; 1: 35-38.

12 Caplan Al. Mesenchymal stem cells. J Orthop Res 1991; 9: 641-650.

13 Owen M. Marrow stromal stem cells. J Cell Sci Suppl 1988; 10: 63-76.

14 Thomson JA, Itskovitz-Eldor J, Shapiro SS, Waknitz MA, Swiergiel JJ, Marshall VS et al. Embryonic stem cell lines derived from human blastocysts. Science 1998; 282: 1145-1147.

15 Gearhart J. New potential for human embryonic stem cells. Science 1998; 282: 1061-1062.

16 Dexter TM, Spooncer E, Schofield R, Lord BI, Simmons P. Haemopoietic stem cells and the problem of self-renewal. Blood Cells 1984; 10 : 315-339.

17 Pittenger MF. Multilineage potential of adult human mesenchymal stem cells. Science 1999; 284: 143-147.

18 Sanchez-Ramos J, Song S, Cardozo-Pelaez F, Hazzi C, Stedeford T, Willing $A$ et al. Adult bone marrow stromal cells differentiate into neural cells in vitro. Exp Neurol 2000; 164: 247-256.

19 Toma C, Pittenger MF, Cahill KS, Byrne BJ, Kessler PD. Human mesenchymal stem cells differentiate to a cardiomyocyte phenotype in the adult murine heart. Circulation 2002; 105: 93-98.

20 Horwitz EM, Le Blanc K, Dominici M, Mueller I, Slaper-Cortenbach I, Marini FC et al. Clarification of the nomenclature for MSC: the International Society for Cellular Therapy position statement. Cytotherapy 2005 7: 393-395.

21 Dominici M, Le Blanc K, Mueller I, Slaper-Cortenbach I, Marini F, Krause $D$ et al. Minimal criteria for defining multipotent mesenchymal stromal cells. The International Society for Cellular Therapy position statement. Cytotherapy 2006; 8: 315-317.

22 Deans RJ, Moseley AB. Mesenchymal stem cells: biology and potential clinical uses. Exp Hematol 2000; 28: 875-884.
23 Tse WT, Pendleton JD, Beyer WM, Egalka MC, Guinan EC. Suppression of allogeneic T-cell proliferation by human marrow stromal cells: implications in transplantation. Transplantation 2003; 75: 389-397.

24 Honczarenko M, Le Y, Swierkowski M, Ghiran I, Glodek AM, Silberstein LE. Human bone marrow stromal cells express a distinct set of biologically functional chemokine receptors. Stem Cells 2006; 24: 1030-1041.

25 Buhring HJ, Battula VL, Treml S, Schewe B, Kanz L, Vogel W. Novel markers for the prospective isolation of human MSC. Ann NY Acad Sci 2007; 1106: 262-271.

26 Caplan Al. Adult mesenchymal stem cells for tissue engineering versus regenerative medicine. J Cell Physiol 2007; 213: 341-347.

27 Keating A. Mesenchymal stromal cells. Curr Opin Hematol 2006; 13 : 419-425.

28 Peister A, Mellad JA, Larson BL, Hall BM, Gibson LF, Prockop DJ. Adult stem cells from bone marrow (MSCs) isolated from different strains of inbred mice vary in surface epitopes, rates of proliferation, and differentiation potential. Blood 2004; 103: 1662-1668.

29 Devine SM, Cobbs C, Jennings M, Bartholomew A, Hoffman R. Mesenchymal stem cells distribute to a wide range of tissues following systemic infusion into nonhuman primates. Blood 2003; 101: 2999-3001.

30 Le Blanc K, Pittenger M. Mesenchymal stem cells: progress toward promise. Cytotherapy 2005; 7: 36-45.

31 Izadpanah R, Trygg C, Patel B, Kriedt C, Dufour J, Gimble JM et al. Biologic properties of mesenchymal stem cells derived from bone marrow and adipose tissue. J Cell Biochem 2006; 99: 1285-1297.

32 Zannettino AC, Paton S, Arthur A, Khor F, Itescu S, Gimble JM et al Multipotential human adipose-derived stromal stem cells exhibit a perivascular phenotype in vitro and in vivo. J Cell Physiol 2008; 214 413-421.

33 Zuk PA, Zhu M, Mizuno H, Huang J, Futrell JW, Katz AJ et al Multilineage cells from human adipose tissue: implications for cell-based therapies. Tissue Eng 2001; 7: 211-228.

34 Zhang Y, Li C, Jiang X, Zhang S, Wu Y, Liu B et al. Human placentaderived mesenchymal progenitor cells support culture expansion of longterm culture-initiating cells from cord blood CD34 + cells. Exp Hematol 2004; 32: 657-664.

35 In 't Anker PS, Noort WA, Scherjon SA, Kleijburg-van der Keur C Kruisselbrink $A B$, van Bezooijen $R L$ et al. Mesenchymal stem cells in human second-trimester bone marrow, liver, lung, and spleen exhibit a similar immunophenotype but a heterogeneous multilineage differentiation potential. Haematologica 2003; 88: 845-852.

36 Roubelakis MG, Pappa KI, Bitsika V, Zagoura D, Vlahou A, Papadaki HA et al. Molecular and proteomic characterization of human mesenchymal stem cells derived from amniotic fluid: comparison to bone marrow mesenchymal stem cells. Stem Cells Dev 2007; 16: 931-952.

37 Tsai MS, Hwang SM, Tsai YL, Cheng FC, Lee JL, Chang YJ. Clonal amniotic fluid-derived stem cells express characteristics of both mesenchymal and neural stem cells. Biol Reprod 2006; 74: 545-551.

38 Tsai MS, Lee JL, Chang YJ, Hwang SM. Isolation of human multipotent mesenchymal stem cells from second-trimester amniotic fluid using a novel two-stage culture protocol. Hum Reprod 2004; 19: 1450-1456.

39 Bieback K, Kern S, Kluter H, Eichler H. Critical parameters for the isolation of mesenchymal stem cells from umbilical cord blood. Stem Cells 2004; 22: 625-634.

40 Erices A, Conget $\mathrm{P}$, Minguell JJ. Mesenchymal progenitor cells in human umbilical cord blood. Br J Haematol 2000; 109: 235-242.

41 Young HE, Steele TA, Bray RA, Hudson J, Floyd JA, Hawkins K et al. Human reserve pluripotent mesenchymal stem cells are present in the connective tissues of skeletal muscle and dermis derived from fetal, adult, and geriatric donors. Anat Rec 2001; 264: 51-62.

42 Gronthos S, Mankani M, Brahim J, Robey PG, Shi S. Postnatal human dental pulp stem cells (DPSCs) in vitro and in vivo. Proc Natl Acad Sci USA 2000; 97: 13625-13630.

43 Huss R, Lange C, Weissinger EM, Kolb HJ, Thalmeier K. Evidence of peripheral blood-derived, plastic-adherent CD34(-/low) hematopoietic stem cell clones with mesenchymal stem cell characteristics. Stem Cells 2000; 18: 252-260.

44 Wagner W, Feldmann Jr RE, Seckinger A, Maurer MH, Wein F, Blake J et al. The heterogeneity of human mesenchymal stem cell preparationsevidence from simultaneous analysis of proteomes and transcriptomes. Exp Hematol 2006; 34: 536-548.

45 Wagner W, Wein F, Seckinger A, Frankhauser M, Wirkner U, Krause U et al. Comparative characteristics of mesenchymal stem cells from human 
bone marrow, adipose tissue, and umbilical cord blood. Exp Hematol 2005; 33: 1402-1416.

46 Kern S, Eichler H, Stoeve J, Kluter H, Bieback K. Comparative analysis of mesenchymal stem cells from bone marrow, umbilical cord blood, or adipose tissue. Stem Cells 2006; 24: 1294-1301.

47 English K, Ryan JM, Tobin L, Murphy MJ, Barry FP, Mahon BP. Cell contact, prostaglandin $\mathrm{E}(2)$ and transforming growth factor beta 1 play nonredundant roles in human mesenchymal stem cell induction of CD4 + CD25(High) forkhead box P3 + regulatory T cells. Clin Exp Immunol 2009; 156: 149-160.

48 Nadig SN, Wieckiewicz J, Wu DC, Warnecke G, Zhang W, Luo S et al. In vivo prevention of transplant arteriosclerosis by ex vivo-expanded human regulatory T cells. Nat Med 2010; 16: 809-813.

49 Toubai T, Paczesny S, Shono Y, Tanaka J, Lowler KP, Malter CT et al. Mesenchymal stem cells for treatment and prevention of graft-versus-host disease after allogeneic hematopoietic cell transplantation. Curr Stem Cell Res Ther 2009; 4: 252-259.

50 Augello A, Tasso R, Negrini SM, Cancedda R, Pennesi G. Cell therapy using allogeneic bone marrow mesenchymal stem cells prevents tissue damage in collagen-induced arthritis. Arthritis Rheum 2007; 56: $1175-1186$.

51 Choi EW, Shin IS, Lee HW, Park SY, Park JH, Nam MH et al. Transplantation of CTLA4lg gene-transduced adipose tissue-derived mesenchymal stem cells reduces inflammatory immune response and improves Th1/Th2 balance in experimental autoimmune thyroiditis. J Gene Med 2011; 13: 3-16.

52 Djouad F, Bouffi C, Ghannam S, Noel D, Jorgensen C. Mesenchymal stem cells: innovative therapeutic tools for rheumatic diseases. Nat Rev Rheumatol 2009; 5: 392-399.

53 Corcione A, Benvenuto F, Ferretti E, Giunti D, Cappiello V, Cazzanti F et al. Human mesenchymal stem cells modulate B-cell functions. Blood 2006; 107: 367-372.

54 Spaggiari GM, Capobianco A, Abdelrazik H, Becchetti F, Mingari MC, Moretta L. Mesenchymal stem cells inhibit natural killer-cell proliferation, cytotoxicity, and cytokine production: role of indoleamine 2,3-dioxygenase and prostaglandin E2. Blood 2008; 111: 1327-1333.

55 Jiang XX, Zhang Y, Liu B, Zhang SX, Wu Y, Yu XD et al. Human mesenchymal stem cells inhibit differentiation and function of monocyte-derived dendritic cells. Blood 2005; 105: 4120-4126.

56 Park MJ, Park HS, Cho ML, Oh HJ, Cho YG, Min SY et al. Transforming growth factor beta-transduced mesenchymal stem cells ameliorate experimental autoimmune arthritis through reciprocal regulation of Treg/Th17 cells and osteoclastogenesis. Arthritis Rheum 2011; 63: 1668-1680.

57 Di Nicola M, Carlo-Stella C, Magni M, Milanesi M, Longoni PD, Matteucci $\mathrm{P}$ et al. Human bone marrow stromal cells suppress T-lymphocyte proliferation induced by cellular or nonspecific mitogenic stimuli. Blood 2002; 99: 3838-3843.

58 Ren G, Zhang L, Zhao X, Xu G, Zhang Y, Roberts Al et al. Mesenchymal stem cell-mediated immunosuppression occurs via concerted action of chemokines and nitric oxide. Cell Stem Cell 2008; 2: 141-150.

59 Nasef A, Ashammakhi N, Fouillard L. Immunomodulatory effect of mesenchymal stromal cells: possible mechanisms. Regen Med 2008; 3: 531-546.

60 Meisel R, Zibert A, Laryea M, Gobel U, Daubener W, Dilloo D. Human bone marrow stromal cells inhibit allogeneic T-cell responses by indoleamine 2,3-dioxygenase-mediated tryptophan degradation. Blood 2004, 103: 4619-4621.

61 Krampera M, Glennie S, Dyson J, Scott D, Laylor R, Simpson E et al. Bone marrow mesenchymal stem cells inhibit the response of naive and memory antigen-specific T cells to their cognate peptide. Blood 2003; 101: 3722-3729.

62 Hoogduijn MJ, Popp F, Verbeek R, Masoodi M, Nicolaou A, Baan C et al. The immunomodulatory properties of mesenchymal stem cells and their use for immunotherapy. Int Immunopharmacol 2010; 10: 1496-1500.

63 Benvenuto F, Ferrari S, Gerdoni E, Gualandi F, Frassoni F, Pistoia V et al. Human mesenchymal stem cells promote survival of T cells in a quiescent state. Stem Cells 2007; 25: 1753-1760.

64 Crop MJ, Baan CC, Korevaar SS, Ijzermans JN, Weimar W, Hoogduijn MJ. Human adipose tissue-derived mesenchymal stem cells induce explosive T-cell proliferation. Stem Cells Dev 2010; 19: 1843-1853.

65 Marigo I, Dazzi F. The immunomodulatory properties of mesenchymal stem cells. Semin Immunopathol 2011; 33: 593-602.
66 Billingham RE. The biology of graft-versus-host reactions. Harvey Lect 1966; 62: 21-78.

67 Schroeder MA, DiPersio JF. Mouse models of graft-versus-host disease: advances and limitations. Dis Model Mech 2011; 4: 318-333.

68 Weng JY, Du X, Geng SX, Peng YW, Wang Z, Lu ZS et al. Mesenchymal stem cell as salvage treatment for refractory chronic GVHD. Bone Marrow Transplant 2010; 45: 1732-1740.

69 Ferrara JL, Abhyankar S, Gilliland DG. Cytokine storm of graft-versus-host disease: a critical effector role for interleukin-1. Transplant Proc 1993; 25(1 Part 2): 1216-1217.

70 Le Blanc K, Rasmusson I, Sundberg B, Gotherstrom C, Hassan M, Uzunel $\mathrm{M}$ et al. Treatment of severe acute graft-versus-host disease with third party haploidentical mesenchymal stem cells. Lancet 2004; 363: 1439-1441.

71 Le Blanc K, Frassoni F, Ball L, Locatelli F, Roelofs H, Lewis I et al. Mesenchymal stem cells for treatment of steroid-resistant, severe, acute graft-versus-host disease: a phase II study. Lancet 2008; 371: 1579-1586.

72 Lazarus HM, Koc ON, Devine SM, Curtin P, Maziarz RT, Holland HK et al. Cotransplantation of HLA-identical sibling culture-expanded mesenchymal stem cells and hematopoietic stem cells in hematologic malignancy patients. Biol Blood Marrow Transplant 2005; 11: 389-398.

73 Sudres M, Norol F, Trenado A, Gregoire S, Charlotte F, Levacher B et al. Bone marrow mesenchymal stem cells suppress lymphocyte proliferation in vitro but fail to prevent graft-versus-host disease in mice. J Immunol 2006; 176: 7761-7767

74 Tisato V, Naresh K, Girdlestone J, Navarrete C, Dazzi F. Mesenchymal stem cells of cord blood origin are effective at preventing but not treating graft-versus-host disease. Leukemia 2007; 21: 1992-1999.

75 Polchert D, Sobinsky J, Douglas G, Kidd M, Moadsiri A, Reina E et al. IFN-gamma activation of mesenchymal stem cells for treatment and prevention of graft versus host disease. Eur J Immunol 2008; 38: $1745-1755$.

76 Krampera M, Cosmi L, Angeli R, Pasini A, Liotta F, Andreini A et al. Role for interferon- $\gamma$ in the immunomodulatory activity of human bone marrow mesenchymal stem cells. Stem Cells 2006; 24: 386-398.

77 Singer NG, Caplan Al. Mesenchymal stem cells: mechanisms of inflammation. Annu Rev Pathol 2011; 6: 457-478.

78 Ringden O, Uzunel M, Sundberg B, Lonnies L, Nava S, Gustafsson J et al. Tissue repair using allogeneic mesenchymal stem cells for hemorrhagic cystitis, pneumomediastinum and perforated colon. Leukemia 2007; 21: 2271-2276.

79 Joo SY, Cho KA, Jung YJ, Kim HS, Park SY, Choi YB et al. Bioimaging for the monitoring of the in vivo distribution of infused mesenchymal stem cells in a mouse model of the graft-versus-host reaction. Cell Biol Int 2011; 35: 417-421.

80 Min CK, Kim BG, Park G, Cho B, Oh IH. IL-10-transduced bone marrow mesenchymal stem cells can attenuate the severity of acute graft-versushost disease after experimental allogeneic stem cell transplantation. Bone Marrow Transplant 2007; 39: 637-645.

81 Baird K, Cooke K, Schultz KR. Chronic graft-versus-host disease (GVHD) in children. Pediatr Clin North Am 2010; 57: 297-322.

82 Zhou H, Guo M, Bian C, Sun Z, Yang Z, Zeng Y et al. Efficacy of bone marrow-derived mesenchymal stem cells in the treatment of sclerodermatous chronic graft-versus-host disease: clinical report. Biol Blood Marrow Transplant 2010; 16: 403-412.

83 Teshima T. Th1 and Th17 join forces for acute GVHD. Blood 2011; 118: 4765-4767.

84 Pan BZL, Cheng H, Song G, Chen C, Zhang Y, Li Z et al. Altered balance between Th1 and Th17 cells in circulation is an indicator for the severity of murine acute GVHD. Immunol Lett 2012; 142: 48-54.

85 Yi TCY, Wang L, Du G, Huang D, Zhao D, Johnston H et al. Reciprocal differentiation and tissue-specific pathogenesis of Th1, Th2, and Th17 cells in graft-versus-host disease. Blood 2009; 114: 3101-3112.

86 Yu YW, Wang D, Liu C, Kaosaard K, Semple K, Anasetti C et al. Prevention of GVHD while sparing GVL effect by targeting Th1 and Th17 transcription factor T-bet and ROR $\gamma$ t in mice. Blood 2011; 118: 5011-5020.

87 Almeida-Porada G, Porada CD, Tran N, Zanjani ED. Cotransplantation of human stromal cell progenitors into preimmune fetal sheep results in early appearance of human donor cells in circulation and boosts cell levels in bone marrow at later time points after transplantation. Blood 2000; 95: 3620-3627. 
88 Noort WA, Kruisselbrink AB, In't Anker PS, Kruger M, van Bezooijen RL, de Paus RA et al. Mesenchymal stem cells promote engraftment of human umbilical cord blood-derived CD34 $(+)$ cells in NOD/SCID mice. Exp Hematol 2002; 30: 870-878.

89 Bartholomew A, Sturgeon C, Siatskas M, Ferrer K, McIntosh K, Patil S et al. Mesenchymal stem cells suppress lymphocyte proliferation in vitro and prolong skin graft survival in vivo. Exp Hematol 2002; 30: 42-48.

90 Masuda S, Ageyama N, Shibata H, Obara Y, Ikeda T, Takeuchi K et al. Cotransplantation with MSCs improves engraftment of HSCs after autologous intra-bone marrow transplantation in nonhuman primates. Exp Hematol 2009; 37: 1250-1257 e1.

91 Nauta AJ, Westerhuis G, Kruisselbrink AB, Lurvink EG, Willemze R, Fibbe WE. Donor-derived mesenchymal stem cells are immunogenic in an allogeneic host and stimulate donor graft rejection in a nonmyeloablative setting. Blood 2006; 108: 2114-2120.

92 Koc ON, Gerson SL, Cooper BW, Dyhouse SM, Haynesworth SE, Caplan Al et al. Rapid hematopoietic recovery after coinfusion of autologousblood stem cells and culture-expanded marrow mesenchymal stem cells in advanced breast cancer patients receiving high-dose chemotherapy. J Clin Oncol 2000; 18: 307-316.

93 Ball LM, Bernardo ME, Roelofs H, Lankester A, Cometa A, Egeler RM et al. Cotransplantation of ex vivo expanded mesenchymal stem cells accelerates lymphocyte recovery and may reduce the risk of graft failure in haploidentical hematopoietic stem-cell transplantation. Blood 2007; 110: 2764-2767.

94 Macmillan ML, Blazar BR, DeFor TE, Wagner JE. Transplantation of ex-vivo culture-expanded parental haploidentical mesenchymal stem cells to promote engraftment in pediatric recipients of unrelated donor umbilical cord blood: results of a phase I-II clinical trial. Bone Marrow Transplant 2009; 43: 447-454.

95 Bernardo ME, Ball LM, Cometa AM, Roelofs H, Zecca M, Avanzini MA et al. Co-infusion of ex vivo-expanded, parental MSCs prevents lifethreatening acute GVHD, but does not reduce the risk of graft failure in pediatric patients undergoing allogeneic umbilical cord blood transplantation. Bone Marrow Transplant 2011; 46: 200-207.

96 Gonzalo-Daganzo R, Regidor C, Martin-Donaire T, Rico MA, Bautista G, Krsnik I et al. Results of a pilot study on the use of third-party donor mesenchymal stromal cells in cord blood transplantation in adults. Cytotherapy 2009; 11: 278-288.

97 Pilat N, Wekerle T. Transplantation tolerance through mixed chimerism. Nat Rev Nephrol 2010; 6: 594-605.

98 Asari S, Itakura S, Rawson J, Ito T, Todorov I, Nair I et al. Mesenchymal stem cells facilitate mixed hematopoietic chimerism induction and prevent onset of diabetes in nonobese diabetic mice. Pancreas 2011; 40: 846-854.

99 Itakura S, Asari S, Rawson J, Ito T, Todorov I, Liu CP et al. Mesenchymal stem cells facilitate the induction of mixed hematopoietic chimerism and islet allograft tolerance without GVHD in the rat. Am J Transplant 2007; 7: 336-346.

100 Pan H, Zhao K, Wang L, Zheng Y, Zhang G, Mai H et al. Mesenchymal stem cells enhance the induction of mixed chimerism and tolerance to rat hind-limb allografts after bone marrow transplantation. J Surg Res 2010; 160: 315-324

101 Wang Y, Liu J, Xu C, Zhang W, Bai L, Li N et al. Bone marrow transplantation combined with mesenchymal stem cells induces immune tolerance without cytotoxic conditioning. J Surg Res 2011; 171: e123-e131.

102 Chan JL, Tang KC, Patel AP, Bonilla LM, Pierobon N, Ponzio NM et al. Antigen-presenting property of mesenchymal stem cells occurs during a narrow window at low levels of interferon-gamma. Blood 2006; 107: 4817-4824.

103 Stagg J, Pommey S, Eliopoulos N, Galipeau J. Interferon-gammastimulated marrow stromal cells: a new type of nonhematopoietic antigen-presenting cell. Blood 2006; 107: 2570-2577.
104 Eliopoulos N. Allogeneic marrow stromal cells are immune rejected by MHC class I- and class II-mismatched recipient mice. Blood 2005; 106: 4057-4065.

105 Sbano P, Cuccia A, Mazzanti B, Urbani S, Giusti B, Lapini I et al. Use of donor bone marrow mesenchymal stem cells for treatment of skin allograft rejection in a preclinical rat model. Arch Dermatol Res 2008; 300: 115-124.

106 Barnes DW, Loutit JF. Treatment of murine leukaemia with x-rays and homologous bone marrow: II. 1957. J Hematother Stem Cell Res 2001 10: 325-334.

107 Bonnet D, Warren EH, Greenberg PD, Dick JE, Riddell SR. CD8(+) minor histocompatibility antigen-specific cytotoxic $\mathrm{T}$ lymphocyte clones eliminate human acute myeloid leukemia stem cells. Proc Natl Acad Sci USA 1999; 96: 8639-8644.

108 Hambach L, Spierings E, Goulmy E. Risk assessment in haematopoietic stem cell transplantation: minor histocompatibility antigens. Best Pract Res Clin Haematol 2007; 20: 171-187.

109 Marijt WA, Heemskerk MH, Kloosterboer FM, Goulmy E, Kester MG van der Hoorn MA et al. Hematopoiesis-restricted minor histocompatibility antigens HA-1- or HA-2-specific T cells can induce complete remissions of relapsed leukemia. Proc Natl Acad Sci USA 2003; 100: 2742-2747.

110 Cooley S, McCullar V, Wangen R, Bergemann TL, Spellman S, Weisdorf DJ et al. KIR reconstitution is altered by T cells in the graft and correlates with clinical outcomes after unrelated donor transplantation. Blood 2005; 106: 4370-4376.

111 Lundqvist A, McCoy JP, Samsel L, Childs R. Reduction of GVHD and enhanced antitumor effects after adoptive infusion of alloreactive Ly49mismatched NK cells from MHC-matched donors. Blood 2007; 109. 3603-3606.

112 Ruggeri L, Mancusi A, Capanni M, Urbani E, Carotti A, Aloisi T et al. Donor natural killer cell allorecognition of missing self in haploidentical hematopoietic transplantation for acute myeloid leukemia: challenging its predictive value. Blood 2007; 110: 433-440.

113 Wang H, Grzywacz B, Sukovich D, McCullar V, Cao Q, Lee AB et al. The unexpected effect of cyclosporin A on CD56 + CD16- and CD56 + CD16 + natural killer cell subpopulations. Blood 2007; 110: 1530-1539.

114 Alyea EP, Canning C, Neuberg D, Daley H, Houde H, Giralt S et al. CD8 + cell depletion of donor lymphocyte infusions using cd8 monoclonal antibody-coated high-density microparticles (CD8-HDM) after allogeneic hematopoietic stem cell transplantation: a pilot study. Bone Marrow Transplant 2004; 34: 123-128.

115 Berger C, Flowers ME, Warren EH, Riddell SR. Analysis of transgenespecific immune responses that limit the in vivo persistence of adoptively transferred HSV-TK-modified donor T cells after allogeneic hematopoietic cell transplantation. Blood 2006; 107: 2294-2302.

116 Porter DL, Levine BL, Bunin N, Stadtmauer EA, Luger SM, Goldstein S et al. A phase 1 trial of donor lymphocyte infusions expanded and activated ex vivo via CD3/CD28 costimulation. Blood 2006; 107: $1325-1331$

117 Baron F, Lechanteur C, Willems E, Bruck F, Baudoux E, Seidel L et al. Cotransplantation of mesenchymal stem cells might prevent death from graft-versus-host disease (GVHD) without abrogating graft-versus-tumor effects after HLA-mismatched allogeneic transplantation following nonmyeloablative conditioning. Biol Blood Marrow Transplant 2010; 16 838-847.

This work is licensed under a Creative Commons (1) Attribution-NonCommercial-NoDerivs 3.0 Unported License. To view a copy of this license, visit http:// creativecommons.org/licenses/by-nc-nd/3.0/ 